\title{
Looking for Empirical Evidence Between Accounting Conservatism and Ownership Structure Towards the Aggressive Tax Avoidance in Public Listed Companies of Indonesia
}

\author{
Mustaruddin Saleh Kurniaty Muhsin \\ Faculty of Economics and Business, Tanjungpura University, Pontianak, INDONESIA
}

\begin{abstract}
Tax aggressiveness is a strategy that still resides in a grey area that is attractive to management for being able to achieve corporate's and government's objectives simultaneously. This study aimed to get empirical evidence about the effect of accounting conservatism and ownership structure against aggressive tax avoidance actions on listed manufacturing companies period 2012-2016. The dependent variable in this study is aggressive tax avoidance proxied by the effective tax rate. While the independent variables are accounting conservatism, institutional ownership, managerial ownership and foreign ownership. This study also had a control variable, those are a return on assets (ROA), debt to total asset ratio (DAR) and capital intensity ratio (CIR). Sampling was done by purposive sampling method with a total of 194 samples from 49 companies for five years. The research result of multiple linear regression analysis showed that accounting conservatism and foreign ownership have a significant negative impact against aggressive tax avoidance. Meanwhile, institutional ownership and managerial ownership have no significant impact on aggressive tax avoidance.
\end{abstract}

Keywords: Effective Tax Rate, Accounting Conservatism, Institutional Ownership, Managerial Ownership and Foreign Ownership.

JEL Classification: G3, M4

DOI: $10.7176 /$ RJFA/10-10-03

Publication date:May $31^{\text {st }} 2019$

\section{Introduction}

In 2016, the Government of Indonesia passed the Act (UU) number 11 on tax amnesty. The Government considers that many of the assets of Indonesian citizens are placed outside the territory of the Unitary State of the Republic of Indonesia, both in liquid and nonlikuid form. In fact, not all of these assets have been reported in the annual tax letter (SPT) by the owner, and many may not have been disclosed as taxpayers avoid paying taxes. The issuance of tax amnesty law shows that there has been aggressive tax avoidance action in Indonesia. With tax amnesty is expected to bridge the interests of the government with the owners of treasures abroad to be willing to reveal his property or withdraw his property to the country. Taxes are a significant cost component for the company and its shareholders, resulting in a desire to reduce the tax burden paid (Hanlon and Slemrod, 2009). Tax aggressiveness is a strategy that is still in the gray area so interesting is done by the management because it is able to achieve corporate and government goals simultaneously (Rusydi and Martani, 2014). Various factors have been investigated to determine the causes of tax evasion. The application of the principle of accounting conservatism in the presentation of financial statements is the practice of lowering profits and net assets in response to bad news but not raising profits and assets in response to good news (Basu, 1997). Dwimulyani (2010) examines the effect of accounting conservatism on income tax disputes. The results of his research show that there is a relationship between accounting conservatism and income tax disputes, because companies tend to try to save taxes with the principle of accounting conservatism. With accounting conservatism, corporate earnings are biased down and corporate tax revenues will also be biased downwards. According to Khurana and Moser (2009) aggressive tax action relates to the large share of ownership owned by the institutional because it leads to greater monitoring efforts by the institutional. Intensive monitoring may hinder opportunistic behavior.

Tax sheltering activities provide earnings benefits and real cash flow advantages to the firm, but may also incur associated costs that may outweigh these benefits if tax avoidance activities are too aggressive or if they arise as a result of managerial incentives relating to the creation and exploitation of information asymmetries to the detriment of shareholders (Ying, Wright and Huang, 2017). According to Atari (2016), managerial ownership and institutional ownership are also factors that can affect the company in performing its tax obligations. The existence of a conflict of interest that arises between the shareholders (principals) and companies (agents) that make managers possible actions that can improve their welfare. If the manager's attitude acts in his own interest, then on the other hand they have to sacrifice some shareholder interests. Control to eliminate the agency problem can be done with an external control or motivational mechanism (Atari, 2016). Foreign ownership is also considered to encourage companies to apply higher corporate governance standards and protection to better minority shareholders (Khanna and Palepu, 2000). This is because foreign ownership focuses on the reputation of the state or its central corporation, so that MNCs attempt to change their operating behavior in order to maintain the 
legitimacy and reputation of the company and foreign ownership in public companies are expected to reduce aggressive tax action. Ying, et al., (2017) suggest that state ownership and control are related with more aggressive tax avoidance strategies and ownership concentration also appears to have a positive influence on tax aggressiveness. The main contribution to be achieved in the research is firstly, showing that the principle of accounting conservatism supported by the Statement of Financial Accounting Standards (PSAK) affects tax aggressiveness. Secondly, it shows empirically that corporate ownership structure is a represent of corporate governance practices, so as to reduce aggressive tax avoidance measures, but not necessarily able to bridge the differences of interests between principal and agent. The objectives of this study are: To analyze and examine the effects of accounting conservatism, institutional ownership, managerial ownership, and foreign ownership on aggressive tax avoidance.

\section{Literature Review and Hypothesis Development}

Jensen and Meckling (1976) describes the agency relationship as a contract between the owners (principal) that involves another person (agent) to perform a service on behalf of the principal and delegate authority entirely to decision making to the agent. Certain shareholders want managers to work with the goal of maximizing shareholder wealth. Company managers may act not to maximize shareholder wealth but maximize their own prosperity. In agency theory, tax planning can facilitate the managerial rent extraction, i.e the opportunistic behavior of managers who are justified to manipulate unsuitable earnings or resource placements (Desai and Dharmapala, 2006). To bridge the conflict of interest in the agency problem, aggressive tax avoidance is used in order to optimize both interests (Rusydi and Martani, 2014). Due to corporate tax avoidance as transfer of resources from the government to shareholders is incomplete given the agency problems characterizing shareholder-manager relations (Desai and Dharmapala, 2009).

Positive accounting theory (descriptive) can explain that accounting policy is a problem for companies and parties concerned with financial statements. According to Watts and Zimmerman (1986), positive accounting theory is used to predict accounting policies that would be chosen by the company under certain conditions. The role of positive accounting theory in this study is to understand that the role of management in the ownership structure of the company will minimize the agency problems that arise because of differences in interests between principals and agents, especially in accounting policies and aggressive tax measures. Indonesia's tax law embraces a self-assessment system, set forth in article 12 of the General Taxation Rules Act. The implementation of selfassessment in Indonesian tax laws seems to provide an opportunity for taxpayers to reduce the amount of tax payable (Brian and Martani, 2014). Hite and McGill (1992) say "aggressive tax planning is a situation where companies have the authority to tax policy and there is a possibility that the policy is unaudited or disputed from the legal side". To measure how well a company manages its taxes is by looking at its effective tax rate through comparison between real taxes paid by companies and pre-tax profits (Karayan and Swenson, 2007).

Watts (2003) defines conservatism as a prudential principle in financial reporting in which the company is not in a hurry to recognize and measure assets and profits and immediately recognize possible losses and liabilities so that there is a difference in the level of verification required to recognize profit recognize the loss. Watts (2003) states the link between taxation and financial reporting can also lead to accounting conservatism in financial reporting. Accounting conservatism produces a downward-biased gain. Mills (1998) states that the measurement in accounting earnings by commercial accounting method is not independent of fiscal measurement, so that accounting conservatism is presumed to result in lower corporate income taxes compared to the results according to the tax authorities.

Research Jaya et al. (2013) indicates that conservatism has no effect on tax avoidance, but the government uses the principle of conservatism to maximize tax revenues and to narrow the space for companies (taxpayers) who want to avoid tax evasion or violation. Research conducted by Ratnasari and Pramudito (2015); Sari et al. (2015) also stated that the use of conservative accounting methods increases the value of ETR. Since the ETR is inversely proportional to ATA, the increase in ETR is an indication of a decrease in aggressive tax avoidance action. Hite and McGill (1992) discover that taxpayers, on average, do not have a preference for tax advice. The subjects tended to disagree with aggressive advice and agree with conservative advice. Based on the description, the proposed hypothesis is as follows:

H1: Accounting Conservatism affect to Aggressive Tax Avoidance.

Khurana and Moser (2009) state that the large concentration of institutional ownership will affect the aggressive tax policy of the company. Institutional share ownership can play an important role in monitoring, disciplining and influencing the manager. Institutional ownership basically sees how far the management is obedient to the rules in generating profits, one of which is to comply with applicable tax regulations (Atari, 2016). Pohan (2009) states that high institutional ownership tends to reduce tax evasion, due to the function of institutional owners to supervise and ensure management to adhere to taxation. Previous empirical studies generally find that tax aggressiveness is related to the representation of active institutional shareholders, even though the results are mixed (Koh, 2003). According studies by Moore (2012); Chen, et al., (2010) and Ying, et al., (2017) find that institutional share 
ownership is negatively related with corporate tax aggressiveness. In contrast, Khurana and Moser (2013), and Khan, Srinivasan, and Tan (2017) find that US firms with higher ownership concentration are generally more tax aggressive. Moreover, prior studies also confirm that the positive relation between tax avoidance and crash risk is attenuated when companies have strong external monitoring mechanisms and thus more risk averse managers, avoid less income tax than companies with less concentrated ownership and control (Kim, Li, and Zhang, 2011; Badertscher, Katz, and Rego, 2013). Based on the description, the proposed hypothesis is as follows: H2: Institutional ownership affect to Aggressive Tax Avoidance.

The desire of management is more to the company's profit growth to get a high bonus, while shareholders more to the value of the company. Hartadinata and Tjaraka (2013) states that managerial ownership negatively affects tax aggressive actions, because management directly feel the benefits of the decision taken also bear the losses that occur if the decision taken wrong, thus making the management to override personal interests in order not to happen aggressive tax action. Chan, Mo, and Zhou (2013) find that the board shareholdings have an impact on tax aggressiveness. Furthermore, Dyreng, Hanlon, and Maydew (2010) find that individual managerial play a significant role in determining the level of tax avoidance those companies undertaken. Based on the description, the proposed hypothesis is: H3: Managerial ownership affect to Aggressive Tax Avoidance.

The majority of businesses have been structured so as to enable tax avoidance in each jurisdiction in which they operate (2004). In a study conducted by Soga et al. (2013) find that the structure of foreign ownership has a negative and significant effect on tax avoidance measures, this is because companies with foreign ownership in it have a higher concern towards the company's reputation. A similar study was also conducted by Asmeri (2015) which showed that the structure of foreign ownership had a significant negative effect on tax evasion. Based on the description, the proposed hypothesis is: H4: Foreign ownership affects Aggressive Tax Avoidance.

\section{Research Method}

\subsection{Types of Research and Sample Selection}

The type of research used is causal research (causal research). The type of data used in this study is quantitative data obtained from secondary data sources of financial statements of manufacturing companies listed on the Indonesia Stock Exchange for five years, 2012-2016 which is downloaded at www .idx.com. The population in this study is 143 companies manufacturing sector listed on Indonesia Stock Exchange. The sampling method is with the specific criteria (purposive sampling) in which the sample is taken based on the following criteria (1) The data of the company's financial statements are available from 2012 to 2016. (2) The company publishes the audit financial statements with the financial year ending in December 31 and presented in Indonesian Rupiah currency (IDR). (3) The Company earns profit during the year of research. (4) Share ownership data is available in the published annual report. The number of samples meeting the sampling criteria was 49 firms over five years with a total of 245 observational data. After examination outlier, then the amount of observation data used in the research as much as 194 data.

\subsection{Research Model}

This study uses three models to find the robustness and consistency of research results. In the first stage, testing will be done to determine the effect of independent variables on the dependent variable. In the second stage, the independent variables of accounting conservatism, managerial ownership, institutional ownership, and foreign ownership to aggressive tax avoidance with control return on asset, debt to total asset ratio and capital intencity ratio to aggressive tax avoidance are examined. Finally the authors do a simulation in considering the influence of control variables on the results of research to obtain the best significance in the research model. The research model is as follows:

$$
\begin{aligned}
& \text { ETRi, } t=\alpha 0+\beta 1 \text { IACi, } t+\beta 2 \text { INSTi, } t+\beta 3 \text { MANAi, } t+\beta 4 \text { FORESi, } t+\varepsilon i, t \\
& \text { ETRi, }=\alpha 0+\beta 1 \text { IACi, } t+\beta 2 \text { INSTi, } t+\beta 3 \text { MANAi, } t+\beta 5 \text { FOREi, } t+\beta 6 \text { ROAi, } t+ \\
& \beta 7 \mathrm{DARi}, \mathrm{t}+\beta 8 \mathrm{CIRi}, \mathrm{t}+\varepsilon \mathrm{i} \\
& \text { ETRi, } t=\alpha 0+\beta 1 \text { IACi, } t+\beta 2 \text { INSTi, } t+\beta 3 \text { MANAi, } t+\beta 5 \text { FOREi, } t+\beta 6 \text { DARi, } t+ \\
& \beta 7 \mathrm{CIRi}, \mathrm{t}+\varepsilon \mathrm{i}, \mathrm{t} \\
& \text { Where: ETR = Aggressive Tax Avoidance which is proxied with Effective Tax Rate (ETR) } \\
& \alpha=\text { Constants } \\
& \beta 1-\beta 8=\text { Regression Coefficient } \\
& \text { IAC = Index of Accounting Conservatism } \\
& \text { INST = Institutional Ownership } \\
& \text { MANA= Managerial Ownership } \\
& \text { FORE = Foreign Ownership } \\
& \text { ROA = Return on Asset } \\
& \text { DAR }=\text { Debt to Total Asset Ratio } \\
& \text { CIR = Capital Intensity Ratio }
\end{aligned}
$$




$$
\varepsilon i, \mathrm{t} \quad=\text { Error term }
$$

\section{Results}

\subsection{Descriptive Statistics}

Table 1 reports the descriptive statistics of regression variables. As indicated before, Dependent variable in this research is aggressive tax avoidance (ATA) which is proxied with Effective Tax Rate (ETR). Karayan and Swenson (2007) state that to measure how well a company manages its taxes is by looking at its effective tax rate through comparison between real taxes paid by companies and pre-tax profits. The existence of effective tax rate (ETR) is a form of calculating the ideal tax rate value calculated in a company. ETR measurements are inversely proportional to aggressive tax avoidance (ATA) action. The higher the ETR the lower the ATA, and the lower the ETR the higher the ATA. The average ETR variable is 0.2476 with a minimum of 0.1576 and a maximum of 0.3376. IAC variable is measured using the Givoly and Hayn (2000) model which states that if accruals are negative, then the earnings are classified as conservative because the earnings are lower than the cash flow earned by the firm for a certain period. The average IAC variable is 0.0135 with a minimum of -0.1479 and a maximum of 0.1502 .

Table 1. Statistic Descriptive

\begin{tabular}{lllllllll}
\hline & ETR & IAC & INST & MANA & FORE & ROA & DAR & CIR \\
\hline Mean & 0.2476 & 0.0135 & 0.5525 & 0.0191 & 0.2961 & 0.0990 & 0.4043 & 0.3308 \\
Median & 0.2503 & 0.0155 & 0.5443 & 0.0000 & 0.1181 & 0.0900 & 0.4044 & 0.3076 \\
Maximum & 0.3376 & 0.1502 & 0.9818 & 0.1797 & 0.9596 & 0.3956 & 0.8100 & 0.8431 \\
Minimum & 0.1576 & -0.1497 & 0.1437 & 0.0000 & 0.0000 & 0.1100 & 0.0977 & 0.0507 \\
Std. Dev. & 0.0356 & 0.0591 & 0.2274 & 0.0406 & 0.3286 & 0.0637 & 0.1495 & 0.1608 \\
Skewness & 0.0127 & -0.1262 & 0.0647 & 2.4782 & 0.5649 & 1.6506 & 0.2124 & 0.8914 \\
Kurtosis & 2.9859 & 2.9519 & 1.8601 & 8.7068 & 1.8220 & 7.9318 & 2.4338 & 3.6680 \\
Jarque-Bera & 0.0068 & 0.5339 & 10.637 & 461.84 & 21.534 & 284.71 & 4.0511 & 29.302 \\
Probability & 0.9965 & 0.7656 & 0.0049 & 0.0000 & 0.0000 & 0.0000 & 0.1319 & 0.0000 \\
Sum & 48.038 & 2.6315 & 107.19 & 3.7242 & 57.451 & 19.101 & 78.434 & 64.183 \\
Sum Sq. Dev. & 0.2458 & 0.6748 & 9.9867 & 0.3187 & 20.844 & 0.7835 & 4.3174 & 4.9965 \\
Observations & 194 & 194 & 194 & 194 & 194 & 194 & 194 & 194 \\
\hline
\end{tabular}

\subsection{Hypothesis testing and Discussion}

Hypothesis testing result is presented in table 2. The first model (Model 1) test is to know the effect of accounting conservatism, ownership structure (institutional, managerial and foreign) to aggressive tax avoidance. Based on the results of data testing, the value of $\mathrm{R} 2$ shows the number 0.6161 or 61.61 percent. The value of $\mathrm{F}$ statistic shows the value of 4.3526 with probability F statistic $0.0000<0.01$ so it can be concluded that independent variables of accounting conservatism, institutional ownership, managerial ownership, and foreign ownership simultaneously affect aggressive tax avoidance. Regression results without control variables show the probability value of independent variables it can be concluded that only accounting conservatism (IAC) variable has an effect on aggressive tax avoidance with significance of 0.05 , while independent variables of managerial ownership, institutional ownership and foreign ownership have no effect on aggressive tax avoidance. In the second stage will be done regression testing by including control variables ROA, DAR and CIR. The purpose of the use of control variables in the study is to avoid the presence of bias in regression, so this variable that causes the relationship between the dependent variable and the independent variable can remain constant and not influenced by other factors.

In Model 2 by adding control variables of DAR and CIR. The results show that the independent variable of accounting conservatism (IAC), foreign ownership (FORE) and with a control variable of DAR are significant effect on aggressive tax avoidance. To maintain consistency of the results that in model 3, we added one more control variable of ROA and hope of obtaining a better significance value. The result of regression fixed effect model in Model 3, after added one more control variable of ROA shows that $R^{2}$ value increased to be 0.6536 or 65.36 percent. The value F-statistic coefficient of 4.7352 with a significance value of 0.0000 . It can be concluded that the independent variables and control variables together provide a significant effect on effective tax rate in the company's manufacturing sector. Testing results for t-statistic is also results that two main independent variables are namely Index of Accounting Conservatism (IAC) and Foreign Ownership (FORE) and three of dependent variables namely DAR, CIR and ROA are also reveal that statistic significant impact toward on aggressive tax avoidance. Hence, Hypothesis 1 (H1) is accepted. The direction of positive relationship indicates that the increase of accounting conservatism variable will increase the value of effective tax rate. Because the effective tax rate relationship is inversely proportional to the aggressive tax avoidance, it is concluded that accounting conservatism has a significant negative effect on aggressive tax avoidance in the manufacturing sector companies listed on the Indonesia Stock Exchange. Therefore, to reduce aggressive tax avoidance action, the company must be 
conservative to the Government Regulation in the preparation of its financial statements.

In table 2 obtained the value of the coefficient of the foreign ownership (FORE) variable is statistically significance at $5 \%$ level, thus hypothesis $4(\mathrm{H} 4)$ is accepted. The direction of a positive relationship indicates that the increase of foreign ownership variable will increase the effective tax rate. So based on the test results it can be concluded that foreign ownership has negative effect on aggressive tax avoidance in manufacturing companies listed on the Indonesia Stock Exchange. This is consistent with the argument of Fauzi (2006) who said that foreign ownership in the company is a party that is deemed to be concerned with improving good corporate governance. Thus, firms with foreign ownership tend to increase supervision to safeguard the reputation of the company and its country of origin as well as to reduce tax avoidance measures.

Table 2. Hypothesis Testing Results by using Fixed Effect Model

\begin{tabular}{|c|c|c|c|c|c|c|}
\hline \multirow{2}{*}{$\begin{array}{l}\text { Variable } \\
\mathrm{C}\end{array}$} & \multicolumn{2}{|c|}{ Model 1} & \multicolumn{2}{|c|}{ Model 2} & \multicolumn{2}{|c|}{ Model 3} \\
\hline & $0.2513^{* * *}$ & $(0.0282)$ & $0.2598 * * *$ & $(0.0322)$ & $0.2808 * * *$ & $(0.0334)$ \\
\hline IAC & $0.0937^{* *}$ & $(0.0425)$ & $0.0871 * *$ & $(0.0418)$ & $0.0707 *$ & $(0.0421)$ \\
\hline INST & -0.0219 & $(0.0486)$ & -0.0431 & $(0.0480)$ & -0.0334 & $(0.0477)$ \\
\hline MANA & -0.1681 & $(0.1896)$ & -0.2654 & $(0.1871)$ & -0.2871 & $(0.1852)$ \\
\hline FORE & 0.0350 & $(0.0245)$ & $0.0365 * *$ & $(0.0278)$ & $0.0430 * *$ & $(0.0237)$ \\
\hline DAR & & & $0.0754 * * *$ & $(0.0272)$ & $0.0659 * *$ & $(0.0273)$ \\
\hline CIR & & & -0.0779 & $(0.0490)$ & $-0.0506 * *$ & $(0.0506)$ \\
\hline ROA & & & & & $-0.1414 * *$ & $(0.0679)$ \\
\hline $\mathrm{R}^{2}$ & 0.6161 & & 0.6428 & & 0.6536 & \\
\hline Adjusted $\mathrm{R}^{2}$ & 0.4749 & & 0.5040 & & 0.5156 & \\
\hline F-statistic & $4.3525^{* * *}$ & & $4.6314 * * *$ & & $4.7352 * * *$ & \\
\hline DW-stat & 2.5293 & & 2.5705 & & 2.5338 & \\
\hline Cho-test & (F-stat) & $4.4291 * * *$ & & & & \\
\hline Hausman- & test (Chi-sq) & $19.3579 * * *$ & & & & \\
\hline
\end{tabular}

Notes: Dependent Variable: ETR; ${ }^{*} \mathrm{p}<0.10 ;{ }^{* *} \mathrm{p}<0.05$; and ${ }^{* * *} \mathrm{p}<0.0$; Figures in parentheses are standard errors robust to heteroscedasticity using White corrected; DW-statistic is Durbin-Watson $d$-test for autocorrelation; number of observation is 194 .

\section{Conclusion}

Based on the results of the analysis and discussion conducted in the previous section, it can be deduced that the model 3 is more appropriated to explain the behavior of aggressive tax avoidance in manufacturing companies listed on the Indonesia Stock Exchange. Accounting conservatism and foreign ownership variables and with three control variables namely DAR, CIR and ROA proved to have a statistically significant effect on the aggressive tax avoidance action. Accounting conservatism and foreign ownership variables and with three control variables namely DAR, CIR and ROA proved to have a statistically significant effect on the aggressive tax avoidance action. The second hypothesis test $(\mathrm{H} 2)$ and the third hypothesis $(\mathrm{H} 3)$ are rejected. Institutional ownership and managerial ownership are not proven to affect aggressive tax avoidance actions on manufacturing companies listed on the Indonesia Stock Exchange. The limitations of this study are: (1) The sample used in this study is only about manufacturing companies. (2) Aggressive tax avoidance measures are only proxied with the effective tax rate. (3). The ownership structure in this study is represented only by institutional ownership, managerial ownership and foreign ownership. (4). the model in this study does not reflect the robustness and consistency in showing the variables that affect the aggressive tax avoidance.

To get effective tax rate not by taking tax avoidance action but by arranging tax payment policy through good tax planning. More intensive supervision should be made to companies with foreign ownership, because empirically there is the possibility of tax evasion by transfer pricing mode. The government needs to conduct taxation workshops on a regular basis, especially among large-scale businessmen to micro small medium enterprises so that people are tax-literate and raise awareness about the importance of tax payments for the development of the Nation and the State. For further research it is suggested to add another proxy to measure aggressive tax avoidance measures such as Cash Effective Tax Rate (CETR) and Book Tax Different (BTD). Then, for further researchers it is advisable to add family ownership variables and government ownership. If the focus is on family ownership structures, it is advisable to use the primary data source obtained in the field. Last, researchers can then simulate other variables such as firm size, company growth, and fiscal loss compensation, to obtain more robust and consistent research results on aggressive tax avoidance measures.

\section{References}

Atari, Jeane. (2016). Pengaruh Kepemilikan Manajerial, Kepemilikan Institusional dan Kebijakan Hutang Terhadap Tax Aggressive: Studi Empiris Pada Perusahaan Transportasi Yang Terdaftar Di Bursa Efek Indonesia Periode 2011-2013. JOM Fekon, 3(1). 
Badertscher, B. A., Katz, S, P., and Rego, S.O. (2013). The separation of ownership and control and corporate tax avoidance, Journal of Accounting and Economics, 56 (2-3), 228-250.

Basu, Sudipta. 1997. The conservatism principle and asymmetric Timeliness of earnings. Journal of Accounting and Economics,.24, 3-37.

Chan, K. H., Mo, Phyllis, L. L., and Zhou, A, Y. (2013). Government ownership, corporate governance and tax aggressiveness:evidence from China. Accounting and Finance, 53 (4), 1029-1051.

Chen, Shuping, Xia Chen, Qiang Cheng. 2010. .Are family firms more tax aggressive than non-family firms?. Journal of Financial Economics, 95 (41-61).

Christensen, John, and Murphy, Richard. 2004. The social irresponsibility of corporate tax avoidance: Taking CSR to the bottom line. Development, 47 (3), 37-44.

Desai, M, A., and Dharmapala, D. (2006). Earnings Management and Corporate Tax Shelters. Journal of Financial Economics 79.

Desai, M. A, and Dharmapala, D. (2009). Corporate Tax Avoidance and Firm Value. The Review of Economics and Statistics, 91 (2), 537-456.

Dyreng, Scott D., Hanlon, Michelle. and Maydew, Edward, L. (2010). The effects of executives on corporate tax avoidance. The Accounting Review, 85 (4), 1163-1189.

Hanlon,M.,Mills, L., and Slemrod, J. (2009). What does tax aggressiveness signal? Evidence from stock price reactions to news about tax shelter involvement. Journal of Public Economics, 93, 126-141.

Hite, P. A., and McGill, G. A. 1992. An Examination of Taxpayer Preference for Aggressive Tax Advice. National Tax Journal, 45 (4), 389-403.

Jaya, T.E., M.Yasser Arafat and Dinda Kartika, (2013). Corporate Governance, Konservatisme Akuntansi dan Tax Avoidance. Simposium Nasional Perpajakan IV.7.

Karayan, J.E., and Swenson, C.W. 'Strategic business tax planning', 2edition, John Willey, 2007

Khan, Mozaffar., Srinivan, Suraj., and Tan, Liang. (2017). Institutional Ownership and Corporate Tax Avoidance: New Evidence. The Accounting Review, 92 (2), 101-122.

Khanna, T., and Palepu. (2000). Is Group affiliation profitable in emerging markets? An analysis of diversified Indian business groups. The Journal of Finance. LV2, 867-891.

Kim, J.B., Li, Y., and Zhang, L. (2011). Corporate tax avoidance and stock price crash risk: Firm-level analysis. Journal of Financial Economics, 100 (3), 639-662.

Koh, P.S. (2003). On the association between institutional ownership and aggressive corporate earnings management in Australia. British Accounting Review, 35 (2), 105-128.

Khurana, I.K. and Moser, W.J.;. (2009). Institusional Ownership and Tax Aggresssiveness. AAA (2010). Financial Accounting and Reporting Section (FARS) Paper.

Khurana, I. and Moser, W.J. (2013). Institutional shareholders' investment horizons and tax avoidance. The Journal of the American Taxation Association, 35 (1), 111-134.

Moore, J.A. (2012). Empirical evidence on the impact of external monitoring on book-tax difference. , Advances in Accounting. 28 (2), 254-269

Penman, Stephen H., Zhang, Xiaojun. (2002). Accounting Conservatism, the quality of earnings, and stock returns. The Accounting review, 77 (2), 237-264.

Ratnasari, Maria M., Pramudito, Batara Wiryo. (2015). Pengaruh Konservatisme Akuntansi, Kepemilikan Manajerial terhadap Tax Avoidance. E-Jurnal Akuntansi Universitas Udayana.

Richardson, G., and Lanis, R. (2013). The impact of board of director oversight characteristics on corporate tax aggressiveness: An empirical analysis. Journal of Accounting and Public Policy, 32, 68-88

Rusydi and Martani. (2014). Pengaruh struktur Kepemilikan Terhadap Aggressive Tax Avoidance. Simposium Nasional Akuntansi XVII Mataram.

Ying, T., Wright, B., and Huang, W. (2017). Ownership structure and tax aggressiveness of Chinese listed companies, International Journal of Accounting \& Information Management, 25 (3), 313-332. 